\title{
Cefpodoxime Proxetil and its By-Products: A Comparative Study as Per EP-7
}

\section{Krishnasarma pathy*}

Head QC/QAIPL research centre, Department of pharmacology, India

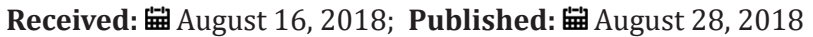

*Corresponding author: Krishnasarma pathy, Head QC/QAIPL research centre, Department of pharmacology, India

\section{Abstract}

Cephalosporins are the highly used Broad-spectrum antibiotics, belong to $\beta$-lactam class. Cephalosporins resemble penicillin in that they have a $\beta$-lactam structure, but the five-member thiazolidine ring characteristic of the penicillin is replaced by a sixmember dihydrothiazine ring. The bactericidal action of beta lactam antibiotics is directly attributable to their ability to react with PBP's. The research work relates to a by-products during process for the industrial manufacture of Cefpodoxime Proxetil. The drug is registered in USP and belongs to 3rd generation drug. It was discovered by Brotzu in fungus Cephalosporium Acremonium which produces a chemical which show antimicrobial activity. Abraham isolated the three fragmentation patterns of cefpodoxime proxetil. Data from this systematic study will help improve the safety and quality of cefpodoxime proxetil types of cephalosporin antibiotics cephalosporin P, cephalosporin N, cephalosporin C.7-ACA is widely used as the substrate for synthesizing cephalosporin antibiotics. Modification of the 7-ACA side-chains resulted in the development of useful antibiotic agents, and the first agent is Cephalothin (cefalotin) was launched by. Eli Lilly Company in 1964 There are many patents which gives the procedure of Synthesis of Cefpodoxime ProxetilStability of three Cefpodoxime proxetil products available in indian market at fridge temperatures $\left(2-8{ }^{\circ} \mathrm{C}\right)$, room temperature $\left(25^{\circ} \mathrm{C}\right)$ and elevated temperature $\left(42^{\circ} \mathrm{C}\right)$. Flow properties, rheological and the physicochemical parameters of both powder and reconstituted powder were used to evaluate the stability of different brands of Cefpodoxime proxetil available in india. The powder of stability samples was eluted through a C18 column with formic acid-methanol-water as the mobile phase. In total, 15 impurities were characterized in commercial samples, including 7 known impurities and 8 new impurities. The structures of these unknown compounds were deduced via comparison.

\section{Introduction}

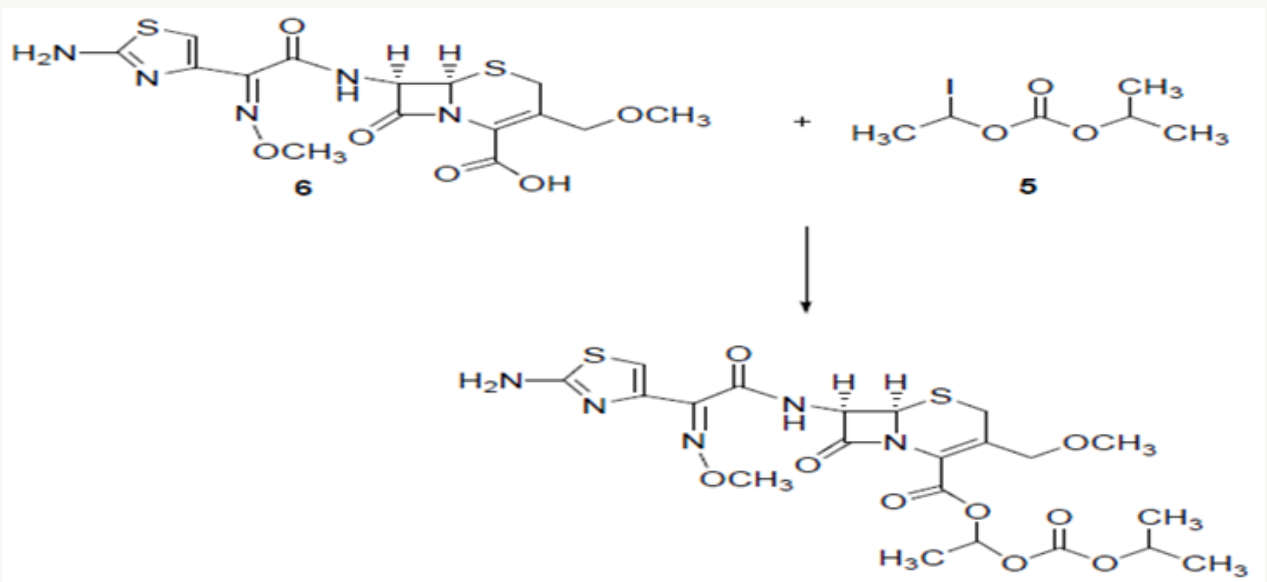

Scheme 1: Synthesis of cefpodoxime proxetil [1]. 
Cefpodoxime proxetil1 is chemically known as 1-(isopropoxycarbonyloxy) ethyl (6R,7R)-7-[(Z)-2--(2-amino-4thiazolyl)-2- (methoxyimino)acetamido]-3-methoxymethyl-3cephem-4-carboxylate. Cefpodoxime proxetil is a potent antibiotic and is of great therapeutic interest in the treatment of acute bronchitis, exacerbations, pneumonia, sinusitis, recurrence of chronic tonisillitis, pharyngitis and acute otitis media. Several methods have been reported in the literature2-4 for the synthesis of cefpodoxime proxetil [1]. Cefpodoxime acid (6) is treated with 1-iodoethyl isopropyl carbonate (5) to produce cefpodoxime proxetil 1, as shown in scheme 1. 1-iodoethyl isopropyl carbonate (5) is prepared5-7 from 1-chloroethyl chloroformte 2, as shown in scheme 1. 1-chloroethyl chloroformate (2) is reacted with isopropanol in presence of a base to produce 1-chloroethyl isoprpopyl carbonate (4). 1-chloroethyl isoprpopyl carbonate (4) on further treatment with sodium iodide results 1-iodoethyl isopropyl carbonate (5).

Cefpodoxime proxtil is a cephalosporin class of antibiotic used for the treatment of bacterial infection. It consists of eight steps namely Methoxilation, condensation side chain formation, work up charcolisation, crystallization and drying [2]. Stage 1: Methoxylation of 7-ACA is carried out with methanol and BF3 complex at low temperature. filter and $\mathrm{pH}$ of the filtrate is adjusted with TEA to get 7-AMCA (Stage-I). Stage 2: 7-AMCA is condensed with MAEM in presence of methanol and TEA. By product is removed by filtration. Filtered mass is treated with activated carbon. Product is isolated by adjusting its $\mathrm{pH}$ with sulphuric acid. It is centrifuged, washed with acetone and dried at $45{ }^{\circ} \mathrm{C}$ to get Cefpodoxime acid. Stage 3 1-Iodoethyl isopropyl carbonate is further subjected to condensation with the Cefpodoxime Acid in the presence of dimethyl acetamide using the 1,8- Diazabicyclo $[5,4,0]$ unde-7-ene (DBU) as a catalyst which on further workup with water \& washing with sodium thiosulfate \& sodium chloride ethyl acetate, cyclo hexane and treatment with Methanol \& EDTA \& its further crystallization using the ammonia solution for $\mathrm{pH}$ adjustment yields the Cefpodoxime Proxetil 10.

Cefpodoxime proxetil an oral, broad-spectrum third generation cephalosporin antibiotic. It has in vitro activity against many common Gram-positive and Gram-negative pathogens associated with common pediatric infections, so it is a useful option for empirical therapy. It is listed in the United States Pharmacopeia $36^{\text {th }}$ Edition, the European Pharmacopeia 7.0 Edition and the Japanese Pharmacopeia $15^{\text {th }}$ Edition. Different analysis methods have been developed and compared to measure impurities and degradation products. Fukutsu et al. identified three degradation products of cefpodoxime proxetil by high-performance liquid chromatography-hyphenated techniques. However, ICH guidelines Q3A require that all impurities (from processing and degradation) be identified above a certain threshold. Yet, currently, a systematic study for identifying cefpodoxime proxetil impurities is not available11-12. Hence, we focused on identifying unknown process impurities and degradation products in cefpodoxime proxetil using a chromatographic system from the European Pharmacopeia 7.0 Edition using liquid chromatography with diode array detection (LC-DAD), multiple stage mass spectrometry (MSn), and liquid chromatography-high-resolution mass spectrometry (LC-HRMS) methods along with stress degradation tests, degradation and mass fragmentation mechanisms of cephalosporins, and related synthesis processes. These studies will inform future quality control and safety of cefpodoxime proxetil products. We characterized 15 impurities including 4 new degradation products and 4 new process impurities, along with 7 known impurities as identified in the European Pharmacopeia. We would discuss these as well as the most likely cause of their appearance and the mass fragmentation pathways of the impurities.

Stability of a pharmaceutical product may be defined as the capability of a formulation in a specific container/closure system to remain within its physical, chemical, microbiological, toxicological, protective and informational specifications [3]. Although there are exceptions, $90 \%$ of the labelled potency is generally recognized as the maximum acceptable potency level [4]. Thus, stability study maintains the product quality, safety and efficacy throughout the product shelf-life [3]. The stability of pharmaceutical products depends on many factors, such as stability of the active pharmaceutical ingredient, the potential interaction between the active ingredient and the excipient, the dosage form, the storage condition, handling and length of time between manufacture and final usage. Although factors like environmental influence like light, moisture and heat are important in stability study of pharmaceutical products [5]. Dry powders for oral suspension are powder mixtures which require reconstitution at the time of administration mostly for paediatric use [6]. We therefore investigated the effect of temperature on the physicochemical characteristics of some oral re constitutable Cefpodoxime proxetil dry powder and suspension available in Nigerian pharmaceutical market and also to be able to select and recommend the best from the series of possible choices. This study specifically aimed to achieve these objectives by applying a simple, accurate and less time-consuming validated UV spectroscopic method for the quantification of Cefpodoxime proxetil in samples subject to variable storage conditions, thus their physicochemical stability assessment over a period of time. Three brands of Cefpodoxime $(40 \mathrm{mg} / 5 \mathrm{~mL}, 50 \mathrm{mg} / 5 \mathrm{mLl}$ and 40 $\mathrm{mg} / 5 \mathrm{mLl}$ ) containing $800 \mathrm{mg}, 1000 \mathrm{mg}$ and $800 \mathrm{mg}$ respectively for reconstitution in water for oral use were used in this study. The brands used (A: Innovator product, B: Generic product-Indian origin, and C: Generic product Indian origin) [7-10].

Physical properties determination18-19 The samples (reconstituted and non-reconstituted) were evaluated for physical stability by determining the aesthetic appeal (odour, taste, colour and texture), sedimentation volume, ease of re-dispersion, viscosity, 
particle size, flow rate, angle of repose, bulk density, tapped density, compressibility index and Hausner's ratio as applicable. All parameters were performed in triplicate 13-15. Powder material and degradation products under different forced degradation conditions: $60{ }^{\circ} \mathrm{C}$ water bath degradation; high-temperature degradation; oxidative degradation, UV degradation; and, UV+ oxidative degradation). Acetonitrile was purchased from Thermo Fisher Scientific. Formic acid (98.0\%) was supplied by SigmaAldrich Co. Ltd. and analytical-grade hydrochloric acid ( $\mathrm{HCl}), \mathrm{NaOH}$ and $\left(\mathrm{H}_{2} \mathrm{O}_{2}, 30 \%\right)$ Merck A milli-Q (Millipore, Billerica, MA) was used to further purify glass-distilled water. RS (Batch17-201802, containing $95.9 \%$ of cefpodoxime, India.

\section{Reference standard and sample solutions preparation}

Approximately 3mg of cefpodoxime proxetil systematic RS was transferred to a $10 \mathrm{~mL}$ volumetric flask, and dissolved in $10 \mathrm{~mL}$ of a mixture of water, acetonitrile and acetic acid (99:99:1, v/v/v). This was the systematic RS solution. Next, $3 \mathrm{mg}$ of cefpodoxime proxetil impurity H RS was added to a $10 \mathrm{~mL}$ volumetric flask and dissolved in 10mL of a mixture of water, acetonitrile and acetic acid (99:99:1, $\mathrm{v} / \mathrm{v} / \mathrm{v}$ ). This was the impurity H RS solution. Then, cefpodoxime proxetil capsule contents $(50 \mathrm{mg})$ were dissolved in $50 \mathrm{~mL}$ of a mixture of water, acetonitrile and acetic acid (100\%) (99:99:1, $\mathrm{v} / \mathrm{v} / \mathrm{v}$ [ [11-13]. This was the sample solution. Cefpodoxime proxetil bulk material $(50 \mathrm{mg}$ ) was dissolved in $50 \mathrm{~mL}$ of a mixture of water, acetonitrile and acetic acid (99:99:1, v/v/v). This was the forced degradation stock solution.

\section{Instrumentation}

The LC/MS system consisted of a 3201 S1-2 binary pump, a 3202 S1-2 vacuum degasser, a 3014 S1-2 column heater, a 3012 S1-2 column switch system, a 3133 S1-2 sampler from SHISEIDO (Tokyo, Japan), an Accela PDA detector (Thermo Fisher Scientific Inc., Waltham, MA) and a $3200 \mathrm{Q}$ TRAP mass detector (Applied Biosystem Inc., California), controlled by Analyst ${ }^{\circledR}$ software (version 1.5.1).

\section{Forced degradation study}

The forced degradation stock solution was transferred and degraded under acidic, basic, $60{ }^{\circ} \mathrm{C}$ water bath, oxidative, UV and high-temperature conditions, separately.

\section{Acid degradation solution}

About $5 \mathrm{~mL}$ of stock solution was transferred into a $25 \mathrm{~mL}$ volumetric flask. Then, $2 \mathrm{~mL}$ of $0.1 \mathrm{~mol} / \mathrm{L}$ hydrochloric acid was added. This mixture could stand for $2 \mathrm{~h}$, and then the acidic solution was neutralized with $2 \mathrm{~mL}$ of $0.1 \mathrm{~mol} / \mathrm{L}$ sodium hydroxide. Base degradation solution: About $5 \mathrm{~mL}$ of stock solution was transferred into a $25 \mathrm{~mL}$ volumetric flask and $2 \mathrm{~mL}$ of $0.1 \mathrm{~mol} / \mathrm{L}$ sodium hydroxide was added and maintained for $2 \mathrm{~h}$. The basic solution was then neutralized with $2 \mathrm{~mL}$ of $0.1 \mathrm{~mol} / \mathrm{L}$ hydrochloric acid16. Oxidative degradation solution: About $5 \mathrm{~mL}$ of stock solution was transferred into a $25 \mathrm{~mL}$ volumetric flask. Then, $1.0 \mathrm{~mL}$ of $10 \%$ hydrogen peroxide solution was added. This mixture was maintained for 2 h. Water bath degradation solution: About $5 \mathrm{~mL}$ of stock solution was transferred into a $25 \mathrm{~mL}$ volumetric flask. This solution was kept in a $60^{\circ} \mathrm{C}$ water bath for $45 \mathrm{~min}$, and the solution could cool to room temperature. UV degradation solution: About $10 \mathrm{~mL}$ of stock solution was placed under UV light $(254 \mathrm{~nm})$ for $12 \mathrm{~h}$. Hightemperature degradation solution: About $100 \mathrm{mg}$ of cefpodoxime proxetil bulk material was placed in an oven at $60{ }^{\circ} \mathrm{C}$ for $2 \mathrm{~h}$. Then $10 \mathrm{mg}$ of the above sample was transferred into a $10 \mathrm{~mL}$ volumetric flask. The sample was dissolved and diluted with a mixture of water, acetonitrile and acetic acid (99:99:1, v/v/v).

\section{Chromatographic Conditions}

The analysis was carried out on a Kromasil 100-5 C18 column (4.6 mm×150 mm, $5 \mu \mathrm{m}$-particle diameter). Mobile phase A contained formic acid-methanol-water (1:400:600, v/v/v). Mobile phase B contained formic acid-methanol-water (1:50:950, v/v/v). UV detection was at $254 \mathrm{~nm}$ and the flow rate was kept at $0.6 \mathrm{~mL} /$ min. Column oven temperature was $25^{\circ} \mathrm{C}$ and the data acquisition time was $165 \mathrm{~min}$. The pump mode was gradient, and the program was as follows, time (min)/A (v/v): B (v/v); T0.01/95:5, T65.0/95:5, $\mathrm{T} 145.0 / 15: 85$, T155.0/15:85, T155.1/95:5, and T165.0/95:5.

\section{Mass Spectrometry}

Tuning and MSn investigation of cefpodoxime proxetil and impurities was carried out using the following optimized MS conditions 16,17 :

a) Electro spray ionization: (EPI) positive ionisation mode, decluster potential (DP) $50 \mathrm{~V}$, entrance potential (EP) $10 \mathrm{~V}$, collision energy (CE) $40 \mathrm{~V}$, curtain gas: $20.0 \mathrm{~L} / \mathrm{h}$. Ion source gas 1 : $65.0 \mathrm{~L} / \mathrm{h}$, ion source gas $2: 60.0 \mathrm{~L} / \mathrm{h}$, ion spray voltage (IS): 5500 $\mathrm{V}$, temperature (TEM): $500.0{ }^{\circ} \mathrm{C}$, and Interface heater. Enhanced MS (EMS) and enhanced product ion (EPI) spectra were acquired from m/z 50 to m/z 1200 in 0.1 amu steps with dwell time of $2.0 \mathrm{~s}$. Analyst software (version 1.5.1) was used for data acquisition and processing. Molecular weights of each component were deduced using protonated.

b) Molecular ions- $([\mathrm{M}+\mathrm{H}]+)$ and were confirmed using minor adduct ions of $[\mathrm{M}+\mathrm{Na}]+$ and $[\mathrm{M}+\mathrm{K}]+$ peaks: High resolution-mass spectrum (HR-MS) investigation was accomplished with a dual gradient Ultimate 3000 HPLC system (Dionex Inc., Sunnyvale, CA) equipped with a LTQ Orbit trap XL high resolution mass spectrometer (Thermo Fisher Scientific Inc.) with the following MS conditions: positive ionization mode, FT cell recording window from $\mathrm{m} / \mathrm{z} 100$ to 1200 , and resolution 60,000. Data processing was performed using Perl script (Quant Merge) software. 


\section{Results and Discussion}

Impurity analysis by HPLC- Bulk materials were analyzed using the HPLC-DAD FIG a and b) and 15 impurity peaks were detected from the two samples. All 15 impurities originated from cefpodoxime proxetil bulk material. To determine the source of impurities, cefpodoxime proxetil bulk material was degraded under alkaline, acidic, $60^{\circ} \mathrm{C}$ water bath, oxidation, hightemperature, and UV irradiation conditions, based on published cephalosporin degradation conditions. Typical chromatograms for the different forced degradation conditions are shown. Mass fragmentation pathway of cefpodoxime proxetil Understanding cefpodoxime proxetil fragmentation pathways can help identify impurity structures. Cefpodoxime proxetil was analyzed in positive ion mode firstly by direct flow injection using a methanol/water (1:1) mixture as the solvent through MSn. Mass spectra and the cefpodoxime proxetil mass fragmentation pathway are shown in Figures 1-3. The primary reason why drugs are formulated as a suspension for reconstitution is inadequate chemical stability of the drug in aqueous vehicle [14]. In this study we investigated the effect of temperature on the physicochemical characteristics of some brands of oral re constitutable Cefpodoxime proxetil to determine their stability profile. All the samples were within the expiry period and registered with appropriate drug regulatory agency in India. The colours of the un reconstituted product varies from off white to cream colour (sample "A") and yellow to brown (sample " $\mathrm{B}$ ") in spite of the fact that sample "C" maintaining its cream colour all through the duration of the study. The colours of individual sample depend on other formulation excipients. The reconstituted samples were banana flavoured, sweet with smooth texture. Chemical stability was analyzed through the drug content assay and by chromatography for possible degradation product of active drug (Cefpodoxime proxetil). The percentage of the labelled claim of the non-reconstituted samples decreased with time, across the different samples and at different storage conditions. Product "B" had the least percentage content across all storage conditions used (Figures 4-6).<smiles>COCC1=C(C(=O)OC(C)OC(=O)OC(C)C)N2C(=O)[C@H](NC(=O)C(=NOC)c3csc(N)n3)[C@H]2SC1</smiles>

Figure 1: structure of cefpodoxime proxetil [1].

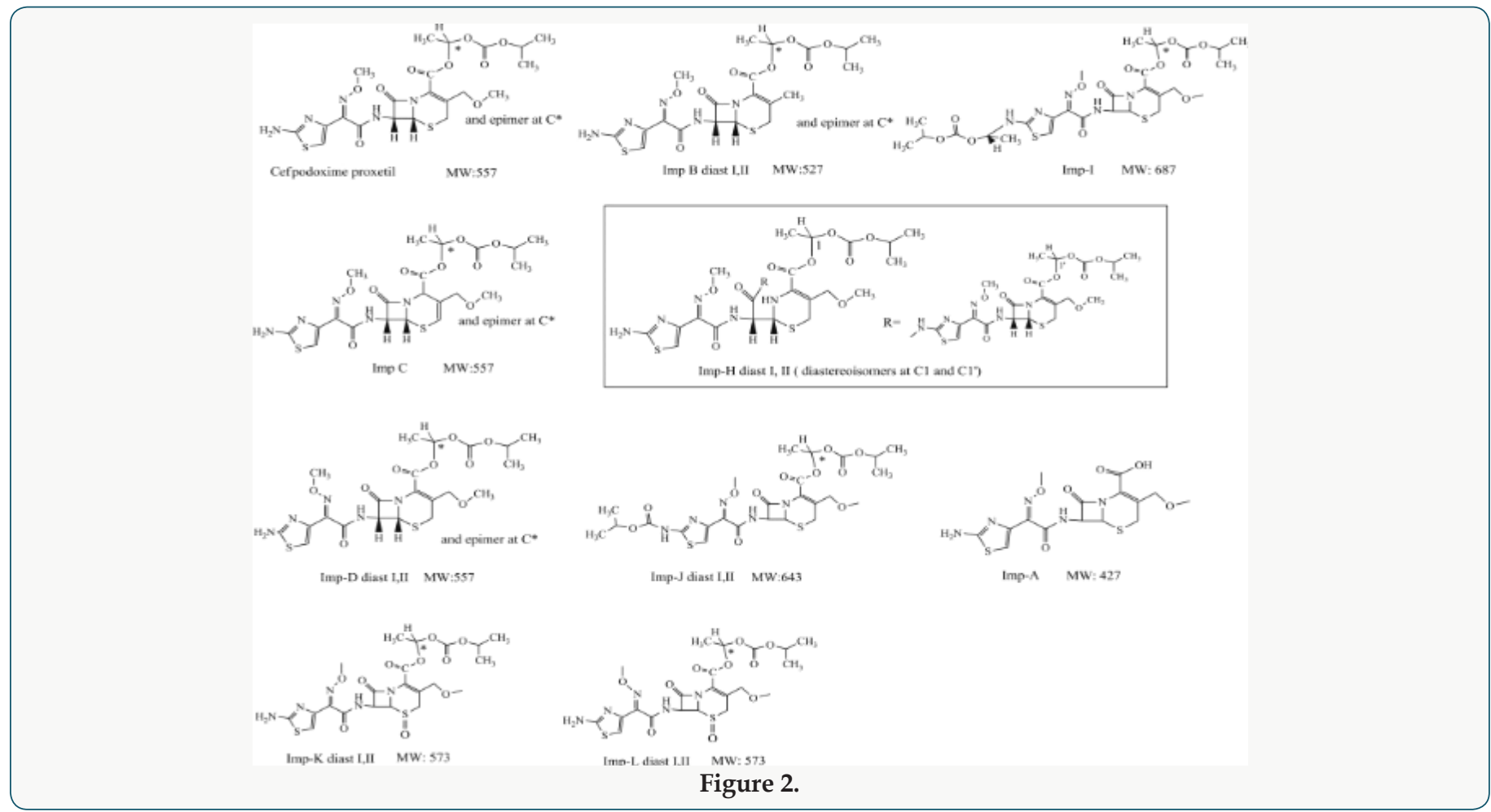




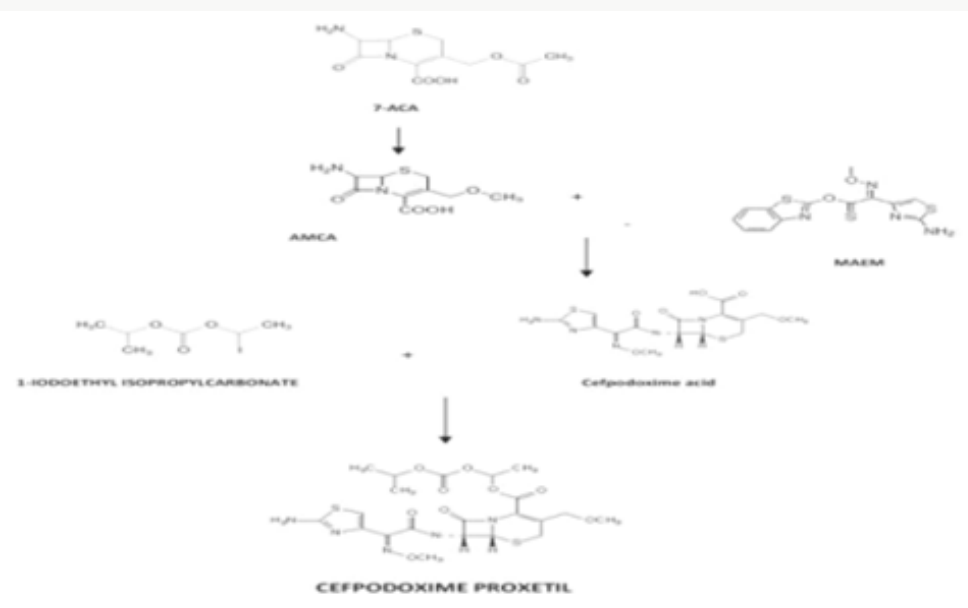

Figure 3.

a

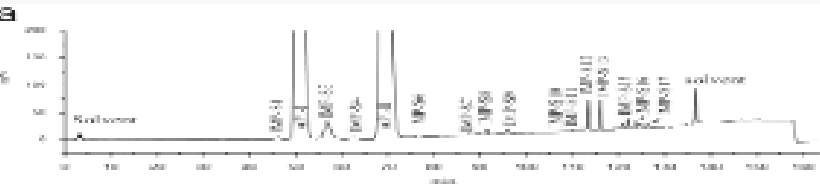

c
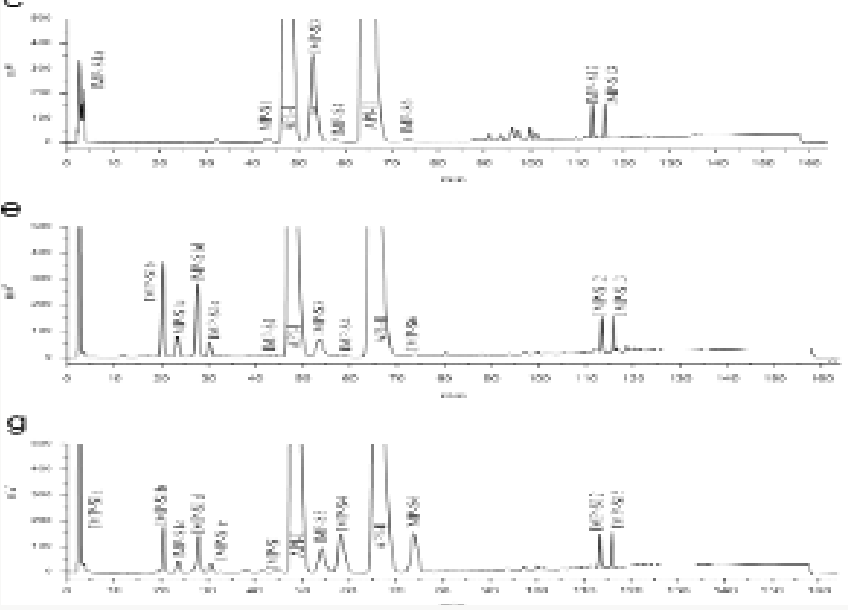

b

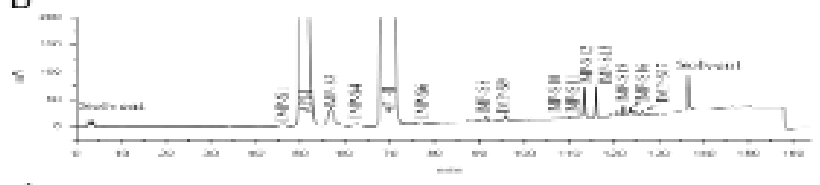

d

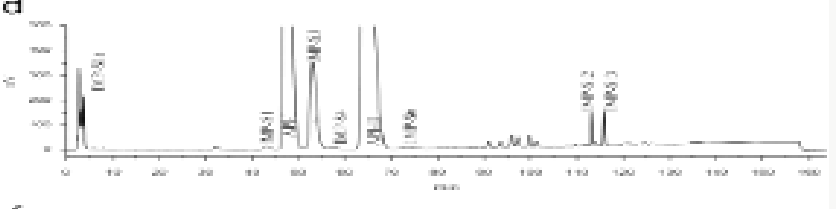

f

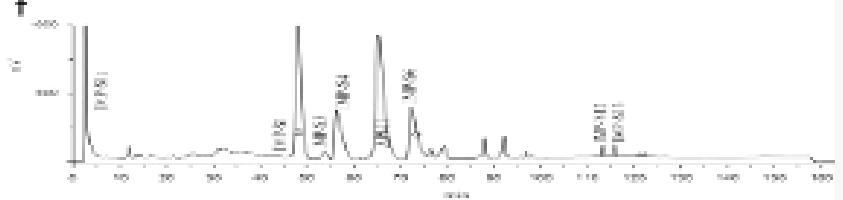

Figure 4.

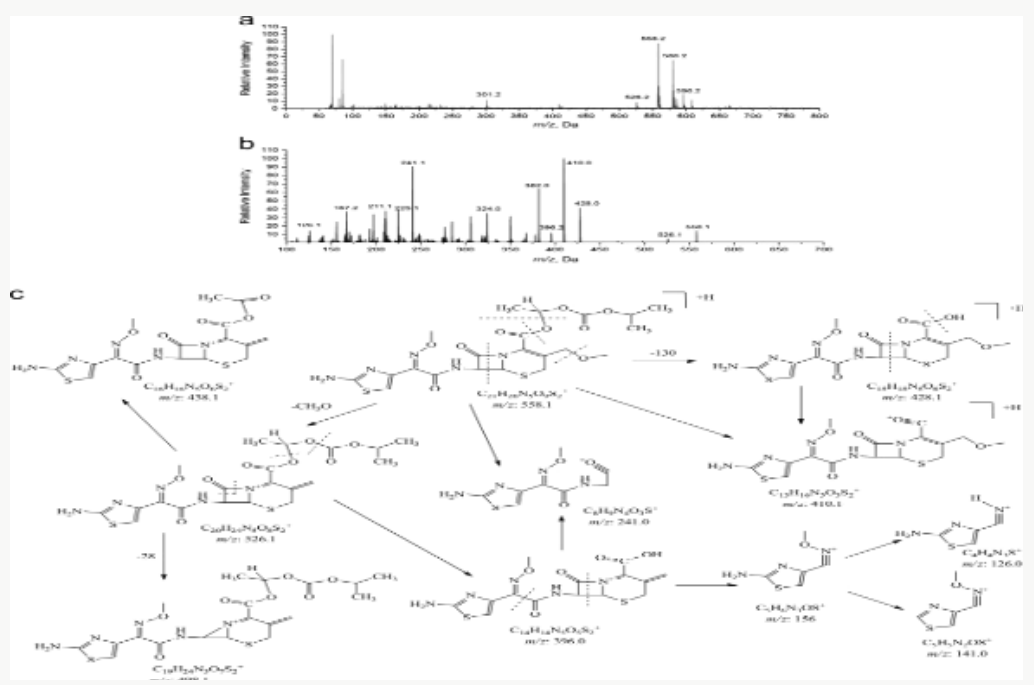

Figure 5. 


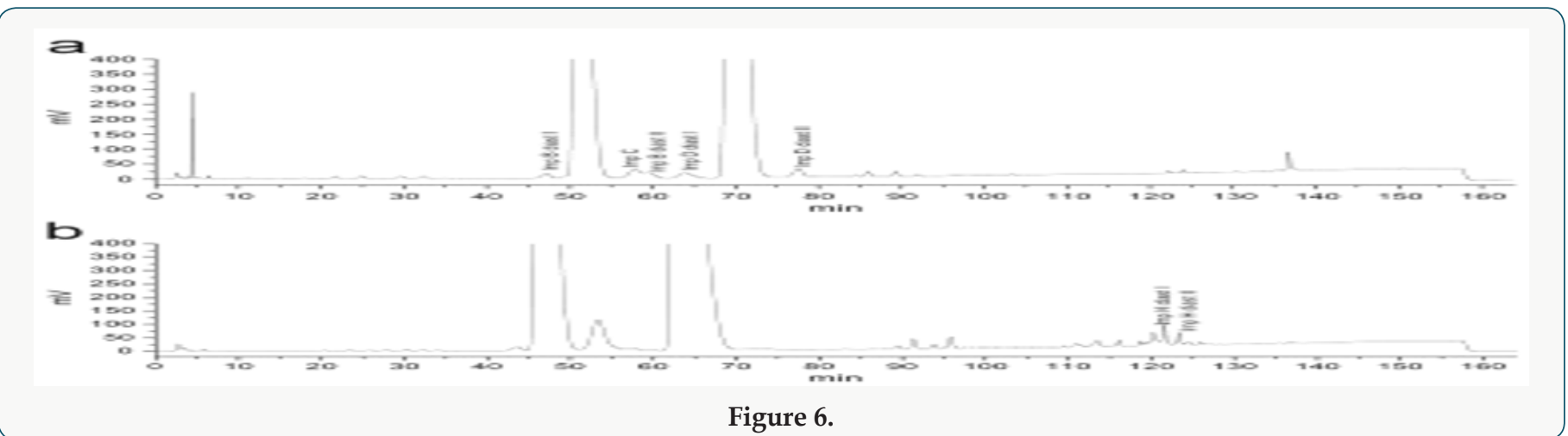

The drug content of samples in the refrigerator were within the USP specification for the duration of the study, except Product "B" whose drug content could not meet the specification on day 90 at room temperature [15]. Degradation of Cefpodoxime occurs either acidic, alkaline, oxidative, photolytic stabilities or combination thereof, but in this study as a result of the type of dissolution medium and the ester functional group present in the drug one is tempted to say hydrolysis must have play an important role in the degradation of Cefpodoxime proxetil [16]. The decrease in drug content of the samples as the sample ages for the non-reconstituted samples were reversed on day 60 , across all brands and storage conditions. The chromatographic analysis of the reconstituted products showed two distinct retention factor values on days 60 and 90 (Tables 1 and 2). The implication of this is that before/on day 60 another product (possibly the degradation product) has been formed which possibly might have a similar wavelength of maximum absorption close to that of the pure Cefpodoxime proxetil, thereby increasing the absorbance value obtained and therefore the corresponding increase in the calculated amount of the Cefpodoxime present in the samples (Further research is ongoing in our laboratory to characterize the product that gave the second Rf value) (Figures 7-10). Changes in concentration may be caused by the mechanisms associated with hydrolytic decomposition and higher temperatures during the long period of storage [17].

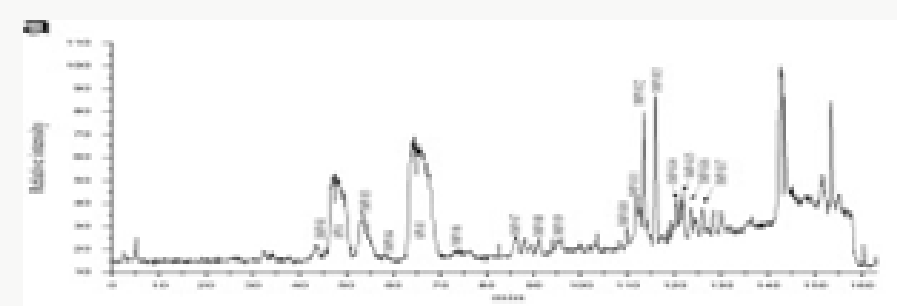

$$
6
$$

b

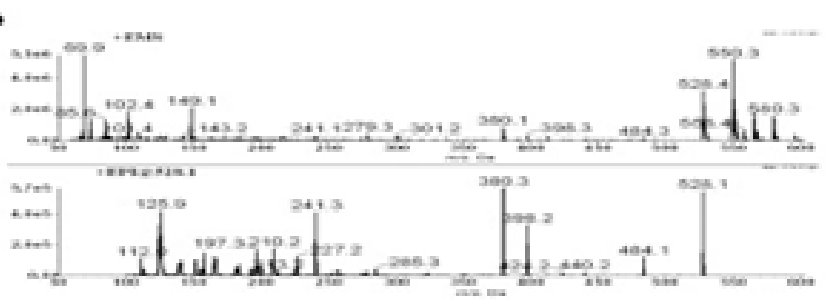

$\mathbf{f}$

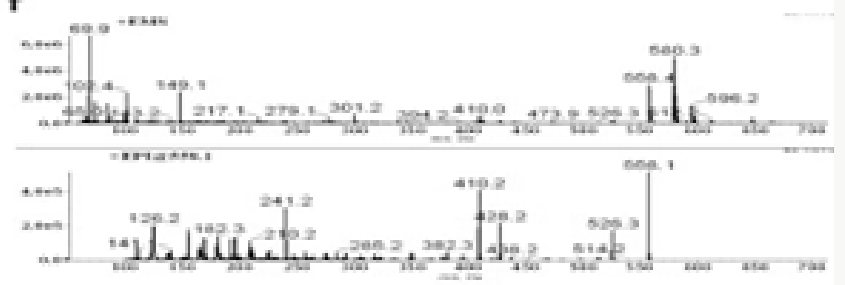

c

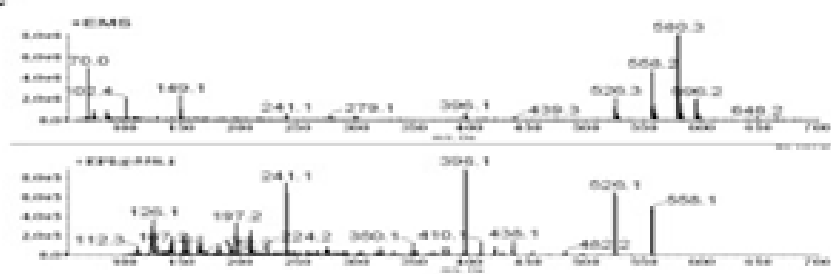

d

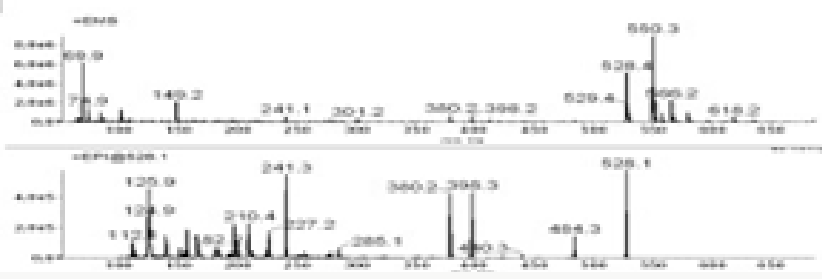

9

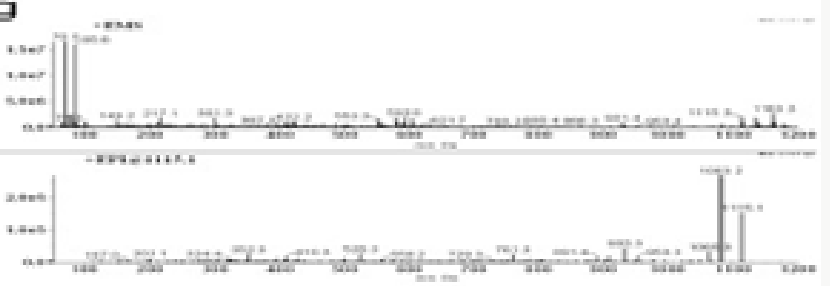

n

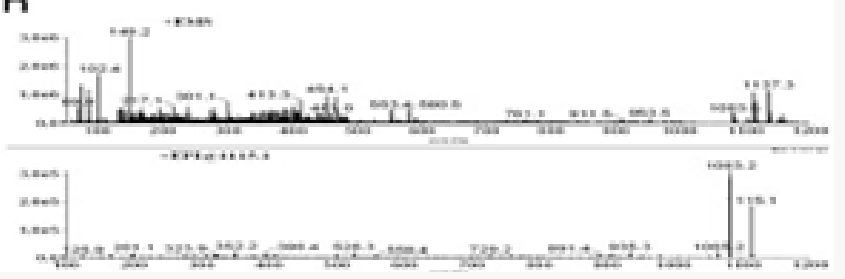

Figure 7. 

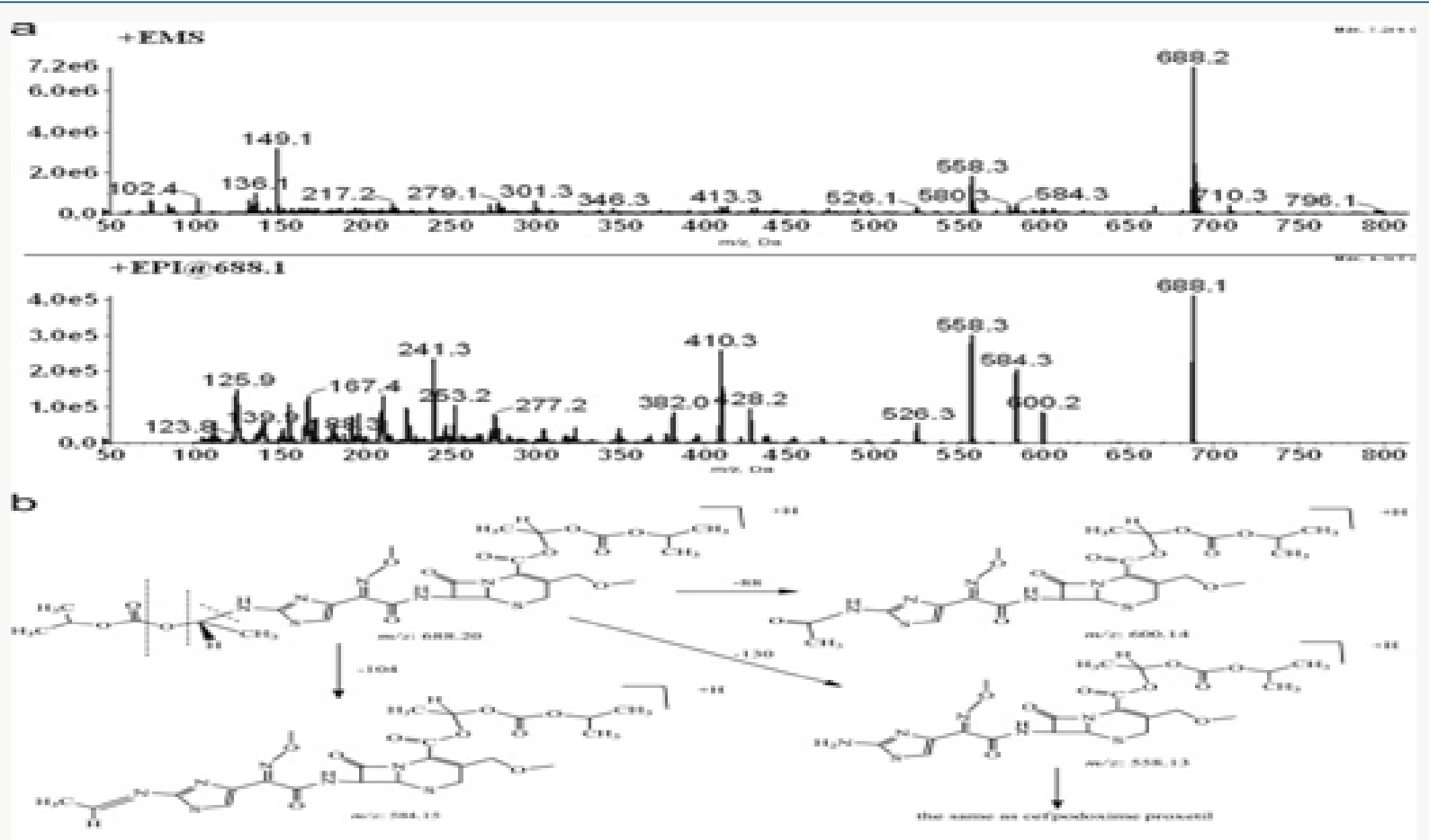

6

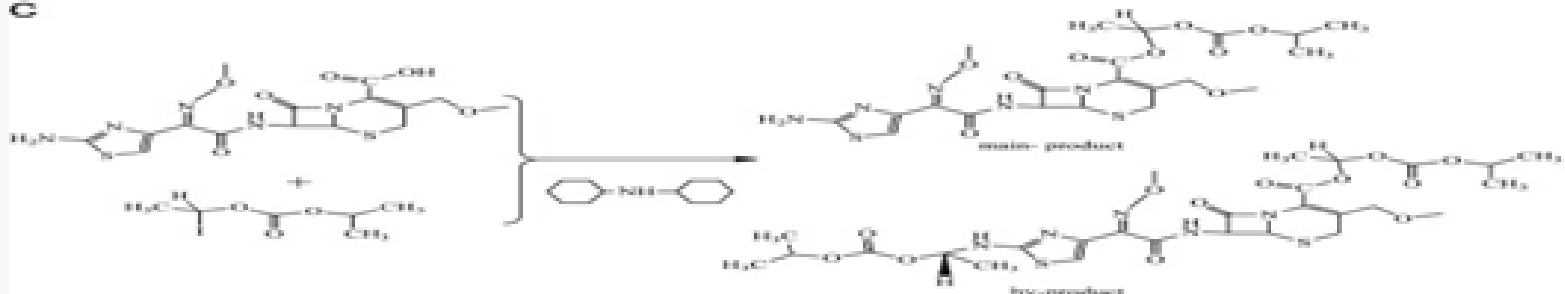

Figure 8.

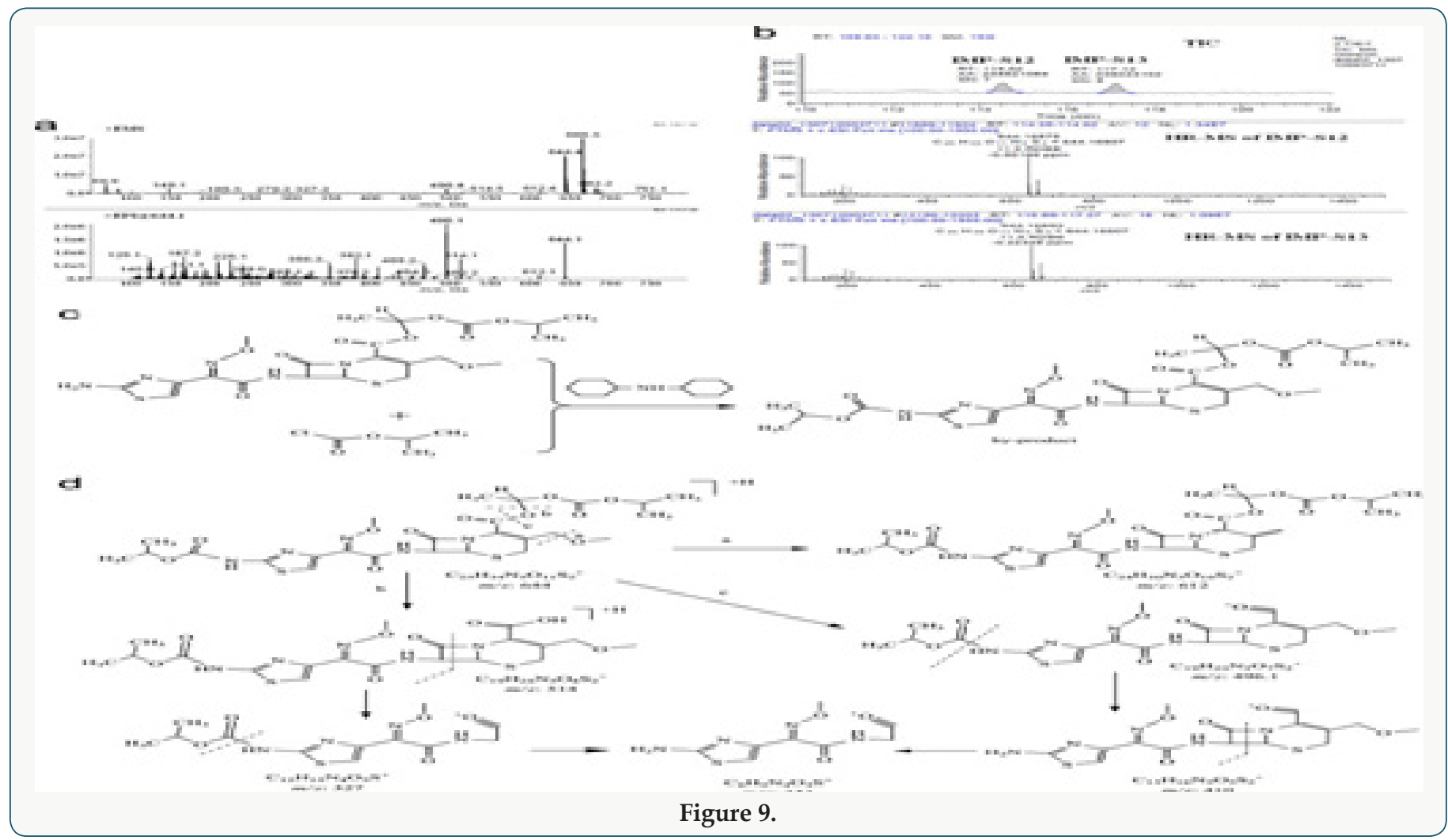

Citation: Krishnasarma p. Cefpodoxime Proxetil and its By-Products: A Comparative Study as Per EP-7. LOJ Med Sci 1(2)-2018. LOJMS. 


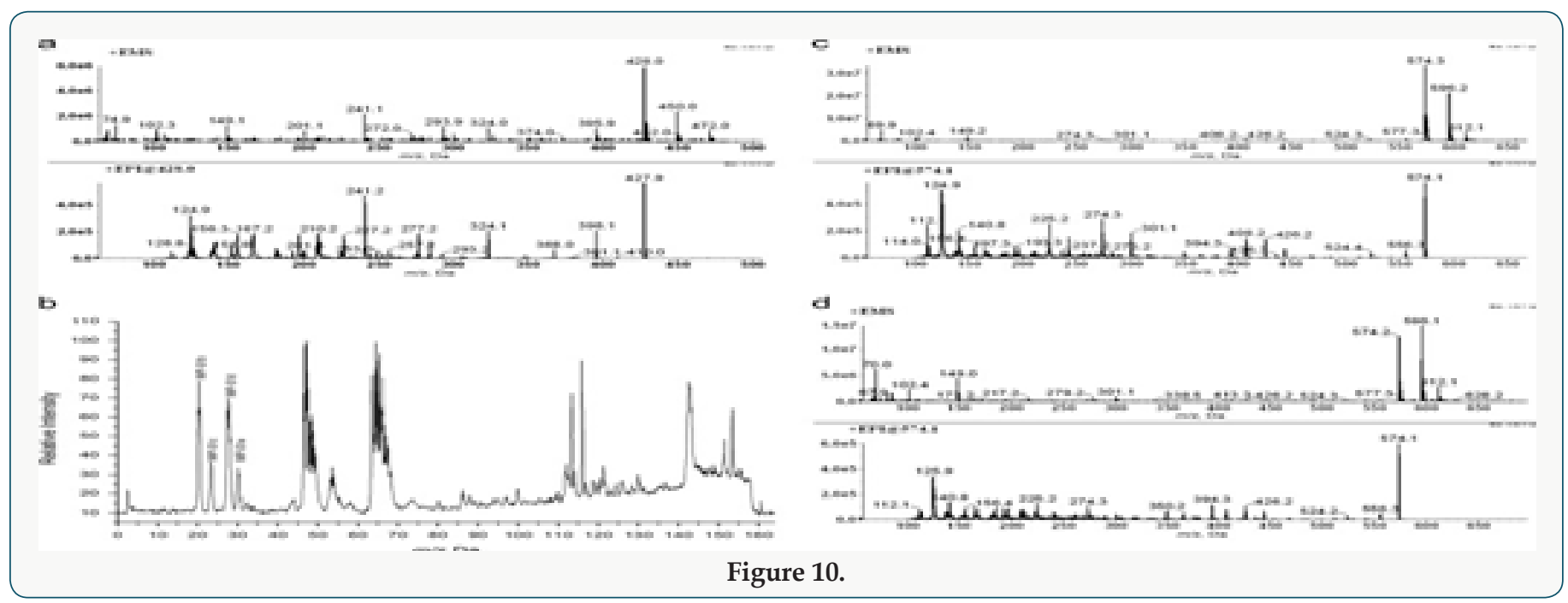

Table 1: Physico-chemical parameters at refrigerator temperature $\left(2{ }^{\circ} \mathrm{C}-8{ }^{\circ} \mathrm{C} / 40 \% \mathrm{Rh}\right)$.

\begin{tabular}{|c|c|c|c|c|c|c|c|c|c|c|c|c|c|c|c|c|c|c|}
\hline & \multicolumn{6}{|c|}{ Product A } & \multicolumn{6}{|c|}{ Product B } & \multicolumn{6}{|c|}{ Product C } \\
\hline & Day 0 & $\begin{array}{c}\text { Day } \\
7\end{array}$ & $\begin{array}{c}\text { Day } \\
14\end{array}$ & $\begin{array}{c}\text { Day } \\
30\end{array}$ & $\begin{array}{c}\text { Day } \\
60\end{array}$ & $\begin{array}{c}\text { Day } \\
90\end{array}$ & $\begin{array}{c}\text { Day } \\
0\end{array}$ & Day 7 & $\begin{array}{c}\text { Day } \\
14\end{array}$ & $\begin{array}{c}\text { Day } \\
\mathbf{3 0}\end{array}$ & $\begin{array}{c}\text { Day } \\
60\end{array}$ & $\begin{array}{c}\text { Day } \\
90\end{array}$ & Day 0 & Day 7 & $\begin{array}{c}\text { Day } \\
14\end{array}$ & $\begin{array}{c}\text { Day } \\
30\end{array}$ & $\begin{array}{c}\text { Day } \\
60\end{array}$ & Day 90 \\
\hline $\begin{array}{l}\% \text { of label } \\
\text { claim } \\
\text { (non- re- } \\
\text { constitut- } \\
\text { ed) }\end{array}$ & 102.88 & - & - & 101.25 & 98.75 & 92.5 & 98.1 & - & - & 97 & 93 & 89 & 101.75 & - & - & 101.25 & 97.5 & 97.5 \\
\hline $\begin{array}{l}\% \text { of label } \\
\text { claim } \\
\text { (reconsti- } \\
\text { tuted) }\end{array}$ & 102.36 & 102.5 & 101.25 & 88.75 & 111.25 & 118.75 & 99 & 98 & 95 & 88 & 112 & 122 & 101.13 & 101.25 & 97.5 & 87.5 & 113.8 & 121.25 \\
\hline pH & 6.33 & 5 & 5 & 4 & 3 & 3 & 5.76 & 5 & 5 & 4 & 3 & 2 & 6.33 & 5 & 5 & 3 & 3 & 3 \\
\hline $\begin{array}{c}\% \\
\text { moisture } \\
\text { content } \\
(\% w / w)\end{array}$ & 2.33 & - & - & 23 & 15 & 14 & 1.33 & - & - & 30.67 & 13 & 13.67 & 0.67 & - & - & 26.67 & 16 & 20.2 \\
\hline $\begin{array}{l}\text { Powders } \\
\text { flow } \\
\text { rate (g/ } \\
\text { sec) }\end{array}$ & 28.01 & - & - & 43.48 & 22.73 & 21.24 & 22.22 & - & - & 37.04 & 22.39 & 20.21 & 37.45 & - & - & 43.48 & 24.59 & 23.44 \\
\hline $\begin{array}{l}\text { Angle of } \\
\text { repose }\left({ }^{\circ}\right)\end{array}$ & 36.03 & - & - & 33.25 & 29.28 & 25.15 & 34.44 & - & - & 33.11 & 29.97 & 23.45 & 34.14 & - & - & 36.7 & 29.28 & 23.45 \\
\hline $\begin{array}{l}\text { Viscosity } \\
\text { of recon- } \\
\text { stituted } \\
\text { samples } \\
\text { (cp) }\end{array}$ & 70.58 & 89.61 & 100.49 & 82.75 & 73.36 & 59.88 & 38.42 & 16.99 & 18.11 & 18.92 & 23.21 & 20.39 & 24.24 & 29.01 & 30.5 & 33.81 & 50.12 & 62.67 \\
\hline $\begin{array}{c}\text { Bulk } \\
\text { density } \\
\text { (g/ mL) }\end{array}$ & 0.5 & - & - & 0.48 & 0.63 & 0.63 & 0.76 & - & - & 0.83 & 0.74 & 0.77 & 0.69 & - & - & 0.74 & 0.91 & 0.95 \\
\hline $\begin{array}{l}\text { Tapped } \\
\text { density } \\
(g / m L)\end{array}$ & 0.59 & - & - & 0.59 & 0.71 & 0.77 & 0.91 & - & - & 1 & 0.77 & 0.83 & 0.87 & - & - & 0.77 & 1 & 1 \\
\hline $\begin{array}{l}\text { Com- } \\
\text { pressibil- } \\
\text { ity index } \\
\text { (CI)\% }\end{array}$ & 15.25 & - & - & 18.64 & 11.27 & 18.18 & 16.48 & - & - & 17 & 3.9 & 7.23 & 20.69 & - & - & 3.9 & 9 & 5 \\
\hline $\begin{array}{l}\text { Hausner's } \\
\text { ratio (HR) }\end{array}$ & 1.18 & - & - & 1.23 & 1.13 & 1.22 & 1.2 & - & - & 1.21 & 1.04 & 1.08 & 1.26 & - & - & 1.04 & 1.1 & 1.05 \\
\hline
\end{tabular}


Table 2: Physico-chemical parameters at room temperature $\left(25^{\circ} \mathrm{C} / 60 \% \mathrm{Rh}\right)$.

\begin{tabular}{|c|c|c|c|c|c|c|c|c|c|c|c|c|c|c|c|c|c|c|}
\hline \multirow{2}{*}{$\begin{array}{l}\text { Parame- } \\
\text { ters }\end{array}$} & \multicolumn{6}{|c|}{ Product A } & \multicolumn{6}{|c|}{ Product B } & \multicolumn{6}{|c|}{ Product C } \\
\hline & Day 0 & Day 7 & $\begin{array}{c}\text { Day } \\
14\end{array}$ & Day 30 & $\begin{array}{c}\text { Day } \\
60\end{array}$ & Day 90 & Day 0 & Day 7 & $\begin{array}{c}\text { Day } \\
14\end{array}$ & $\begin{array}{c}\text { Day } \\
30\end{array}$ & $\begin{array}{c}\text { Day } \\
60\end{array}$ & $\begin{array}{c}\text { Day } \\
90\end{array}$ & Day 0 & $\begin{array}{c}\text { Day } \\
7\end{array}$ & $\begin{array}{c}\text { Day } \\
14\end{array}$ & $\begin{array}{c}\text { Day } \\
30\end{array}$ & $\begin{array}{c}\text { Day } \\
60\end{array}$ & $\begin{array}{c}\text { Day } \\
90\end{array}$ \\
\hline 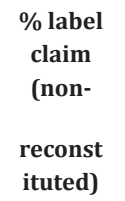 & 102.88 & - & - & 100.75 & 101.25 & 97.5 & 98.1 & - & - & 97 & 97 & 95 & 101.75 & - & - & 101 & 96.25 & 95 \\
\hline $\begin{array}{l}\text { \%label } \\
\text { claim(re- } \\
\text { constitut- } \\
\text { ed) }\end{array}$ & 102.36 & 101.25 & 97.5 & 83.75 & 110 & 121.25 & 99 & 97 & 94 & 71 & 118 & 121 & 101.13 & 98.75 & 92.5 & 77.5 & 116.25 & 110 \\
\hline pH & 6.33 & 5.5 & 4 & 3 & 3 & 3 & 5.67 & 5.5 & 4 & 3 & 3 & 3 & 6.33 & 5.5 & 4 & 3 & 3 & 3 \\
\hline $\begin{array}{c}\% \\
\text { moisture } \\
\text { content } \\
(\% w / w)\end{array}$ & 2.33 & - & - & 10.33 & 11 & 8.67 & 1.33 & - & - & 6.67 & 6.67 & 6.1 & 0.67 & - & - & 3.33 & 4.33 & 7.33 \\
\hline $\begin{array}{l}\text { Powders } \\
\text { flow } \\
\text { rate (g/ } \\
\text { sec) }\end{array}$ & 28.01 & - & - & 31.25 & 26.32 & 28.4 & 22.22 & - & - & 21.74 & 25.42 & 21.07 & 37.45 & - & - & 38.46 & 23.08 & 30.5 \\
\hline $\begin{array}{l}\text { Angle of } \\
\text { repose } \\
\left(^{\circ}\right)\end{array}$ & 36.03 & - & - & 40.4 & 31.48 & 25.8 & 34.44 & - & - & 33.99 & 27.55 & 26.77 & 34.14 & - & - & 36.87 & 28.61 & 24.42 \\
\hline $\begin{array}{l}\text { Viscosity } \\
\text { of recon- } \\
\text { stituted } \\
\text { samples } \\
\text { (cp) }\end{array}$ & 70.58 & 70.6 & 35.78 & 24.17 & 17.53 & 15.98 & 38.42 & 15.42 & 13.74 & 20.52 & 23.56 & 22.77 & 24.24 & 37.24 & 38.83 & 114.31 & - & - \\
\hline $\begin{array}{c}\text { Bulk } \\
\text { density } \\
(\mathrm{g} / \mathrm{mL})\end{array}$ & 0.5 & - & - & 0.5 & 0.67 & 0.74 & 0.76 & - & - & 0.83 & 0.83 & 0.83 & 0.69 & - & - & 0.83 & 0.91 & 0.74 \\
\hline $\begin{array}{l}\text { Tapped } \\
\text { density } \\
(\mathrm{g} / \mathrm{mL})\end{array}$ & 0.59 & - & - & 0.59 & 0.77 & 1 & 0.91 & - & - & 1 & 0.91 & 0.91 & 0.87 & - & - & 0.91 & 1 & 0.95 \\
\hline $\begin{array}{l}\text { Com- } \\
\text { pressibil- } \\
\text { ity index } \\
\text { (CI)\% }\end{array}$ & 15.25 & - & - & 15.25 & 12.99 & 26 & 16.48 & - & - & 17 & 8.79 & 8.79 & 20.69 & - & - & 8.79 & 9 & 22.11 \\
\hline $\begin{array}{l}\text { Hausner's } \\
\text { ratio (HR) }\end{array}$ & 1.18 & - & - & 1.18 & 1.15 & 1.35 & 1.2 & - & - & 1.21 & 1.09 & 1.09 & 1.26 & - & - & 1.09 & 1.1 & 1.05 \\
\hline
\end{tabular}

Weakly acidic or basic drugs show good solubility because of ionization and thus their degradation rate is faster. For the reconstituted samples, the $\mathrm{pH}$ decreases as the suspension ages across all the storage conditions and brands (Tables 3). The decrease in $\mathrm{pH}$ value is expected Cefpodoxime being an ester which readily hydrolysed in water to form carboxylic acid, though the acid produced is either poorly soluble or it exceed its solubility product thereby leading to product colour change or cloudiness [18]. This explains the colour changes earlier discussed. Most disperse systems are stable over a $\mathrm{pH}$ range of 4-8. The $\mathrm{pH}$ of the sample decreases as the samples ages. Products " $\mathrm{A}$ " and " $\mathrm{C}$ " have similar $\mathrm{pH}$ variation, although the $\mathrm{pH}$ of product " $\mathrm{B}$ " (3.00) deviate from the standard $\mathrm{pH}$ range stated above as early as day 14 at elevated temperature while, the $\mathrm{pH}$ values of products " $\mathrm{A}$ " and "C" only deviated from the standard range on day 60 across the storage conditions. The three brands evaluated were banana flavoured and sweet to taste throughout the duration of the study for refrigerated and room temperature conditions while the taste turned sour on the 30th day for all the brands at elevated temperature. Sour tastes rely on ion current to conduct the taste signal, thus stronger ionic taste. Recall that hydrolysis of Cefpodoxime lead to more ionic degradation products. Particle size has profound effect on the dissolution of a formulation. The bigger the particle size the lower the dissolution rate and the less intense the taste of the particle. The particle sizes for products "A" and "C" were similar and significantly smaller than that of product "B". Within the first 30 days of this study all the 
reconstituted samples were of smooth and sticky texture except for those kept in the refrigerator which is smooth. The increase in temperature at both room and elevated temperature might

\section{Table 3.}

\begin{tabular}{|c|c|c|c|c|c|c|c|}
\hline $\begin{array}{l}\text { Peak } \\
\text { No. }\end{array}$ & $\begin{array}{l}\text { Peak } \\
\text { name }\end{array}$ & Component name & $\begin{array}{c}\text { Retention } \\
\text { time (min) }\end{array}$ & MW & Formula & $\begin{array}{l}{[\mathrm{M}+\mathrm{H}]} \\
{[\mathrm{M}+\mathrm{Na}]}\end{array}$ & Typical fragmental ion peak \\
\hline 1 & IMP-S1 ${ }^{\mathrm{a}}$ & Imp B diast $I^{a}$ & 46.3 & 527 & $\mathrm{C}_{20} \mathrm{H}_{25} \mathrm{~N}_{5} \mathrm{O}_{8} \mathrm{~S}_{2}$ & 528,550 & $484,440,424,398,380,241,210,197,126$ \\
\hline 2 & API-1 & $\begin{array}{l}\text { Cefpodoxime prox- } \\
\text { etil diast I }\end{array}$ & 50.1 & 557 & $\mathrm{C}_{21} \mathrm{H}_{27} \mathrm{~N}_{5} \mathrm{O}_{9} \mathrm{~S}_{2}$ & 558,580 & $\begin{array}{c}526,428,410,382,324,306,285,241,225 \\
211,167,156,126\end{array}$ \\
\hline 3 & IMP-S3 & Imp B diast II ${ }^{\mathrm{a}}$ & 56.9 & 527 & $\mathrm{C}_{20} \mathrm{H}_{25} \mathrm{~N}_{5} \mathrm{O}_{8} \mathrm{~S}_{2}$ & 528,550 & $484,440,424,398,380,241,210,197,126$ \\
\hline & & $\operatorname{Imp} C^{a}$ & 56.9 & 557 & $\mathrm{C}_{21} \mathrm{H}_{27} \mathrm{~N}_{5} \mathrm{O}_{9} \mathrm{~S}_{2}$ & 558,580 & $\begin{array}{c}526,498,482,438,428,396,378,350,322, \\
241,210,142,126\end{array}$ \\
\hline 4 & IMP-S4 ${ }^{\mathrm{a}}$ & Imp-D diast $\mathrm{I}^{\mathrm{a}}$ & 62.7 & 557 & $\mathrm{C}_{21} \mathrm{H}_{27} \mathrm{~N}_{5} \mathrm{O}_{9} \mathrm{~S}_{2}$ & 558,580 & $526,428,410,320,241,211,156,126$ \\
\hline 5 & API-2 & $\begin{array}{l}\text { Cefpodoxime prox- } \\
\text { etil diast II }\end{array}$ & 68.6 & 557 & $\mathrm{C}_{21} \mathrm{H}_{27} \mathrm{~N}_{5} \mathrm{O}_{9} \mathrm{~S}_{2}$ & 558,580 & $\begin{array}{c}526,428,410,382,324,306,285,241,225 \\
211,167,156,126\end{array}$ \\
\hline 6 & IMP-S6 & Imp-D diast II & 76.9 & 557 & $\mathrm{C}_{21} \mathrm{H}_{27} \mathrm{~N}_{5} \mathrm{O}_{9} \mathrm{~S}_{2}$ & 558,80 & $526,428,410,320,241,211,156,126$ \\
\hline 7 & IMP-S7 & Imp-I $\underline{\underline{b}}$ & 87.6 & 687 & $\mathrm{C}_{27} \mathrm{H}_{37} \mathrm{~N}_{5} \mathrm{O}_{12} \mathrm{~S}_{2}$ & 688,710 & $\begin{array}{c}600,584,558,526,428,410,382,277,241 \\
167,126\end{array}$ \\
\hline 12 & IMP-S12 & Imp-J diast I $\underline{\underline{b}}$ & 113.5 & 643 & $\mathrm{C}_{25} \mathrm{H}_{33} \mathrm{~N}_{5} \mathrm{O}_{11} \mathrm{~S}_{2}$ & 644,666 & $612,514,496,468,382,350,225,167,125$ \\
\hline 13 & IMP-S13 & Imp-J-Diast II ${ }^{\underline{b}}$ & 116.1 & 643 & $\mathrm{C}_{25} \mathrm{H}_{33} \mathrm{~N}_{5} \mathrm{O}_{11} \mathrm{~S}_{2}$ & 644,666 & $612,514,496,468,382,350,225,167,125$ \\
\hline 15 & IMP-S15 & Imp-H diast $\mathrm{I}^{\mathrm{a}}$ & 122.2 & 1114 & $\mathrm{C}_{42} \mathrm{H}_{54} \mathrm{~N}_{10} \mathrm{O}_{18} \mathrm{~S}_{4}$ & 1115,1137 & $\begin{array}{c}1083,1051,953,935,909,761,526,500,396, \\
352\end{array}$ \\
\hline 16 & IMP-S16 & Imp-H diast II ${ }^{a}$ & 123.9 & 1114 & $\mathrm{C}_{42} \mathrm{H}_{54} \mathrm{~N}_{10} \mathrm{O}_{18} \mathrm{~S}_{4}$ & 1115,1137 & $\begin{array}{c}1083,1051,953,935,909,761,526,500,396, \\
352,\end{array}$ \\
\hline $1 \mathrm{a}$ & IMP-S1a & $\operatorname{Imp} A^{a}$ & 2.72 & 427 & $\mathrm{C}_{15} \mathrm{H}_{17} \mathrm{~N}_{5} \mathrm{O}_{6} \mathrm{~S}_{2}$ & 428,450 & $396,368,324,272,241,210,167,156,125$ \\
\hline $1 b$ & IMP-S1b & Imp K Diast I $\underline{\underline{b}}$ & 20.27 & 573 & $\mathrm{C}_{21} \mathrm{H}_{27} \mathrm{~N}_{5} \mathrm{O}_{10} \mathrm{~S}_{2}$ & 574,596 & $\begin{array}{c}556,524,426,408,394,301,274,225,156 \\
125\end{array}$ \\
\hline $1 \mathrm{c}$ & IMP-S1c & Imp L Diast I ${ }^{\underline{b}}$ & 23.34 & 573 & $\mathrm{C}_{21} \mathrm{H}_{27} \mathrm{~N}_{5} \mathrm{O}_{10} \mathrm{~S}_{2}$ & 574,596 & $556,524,426,394,350,274,225,125$ \\
\hline $1 d$ & IMP-S1d & Imp K Diast II ${ }^{\underline{b}}$ & 27.61 & 573 & $\mathrm{C}_{21} \mathrm{H}_{27} \mathrm{~N}_{5} \mathrm{O}_{10} \mathrm{~S}_{2}$ & 574,596 & $\begin{array}{c}556,524,426,408,394,301,274,225,156, \\
125\end{array}$ \\
\hline $1 \mathrm{e}$ & IMP-S1e & Imp L Diast II $\underline{\underline{b}}$ & 30.15 & 573 & $\mathrm{C}_{21} \mathrm{H}_{27} \mathrm{~N}_{5} \mathrm{O}_{10} \mathrm{~S}_{2}$ & 574,596 & $556,524,426,394,350,274,225,125$ \\
\hline
\end{tabular}

\section{Conclusion}

The purpose of stability testing is to provide evidence on how the quality of a drug substance or drug product varies with time under the influence of a variety of environmental factors, and it enables us to predict the storage condition, predict the period in which the product should be re-tested and finally determine the product shelf life. This research studied three brands of Cefpodoxime proxetil poeder (Products A, B and C) at potential temperature of exposures, which shows that the refrigerator temperature condition $\left(2{ }^{\circ} \mathrm{C}-8\right.$ ${ }^{\circ} \mathrm{C} / 40 \% \mathrm{Rh}$ ) is best for storing the reconstituted suspensions and the non-reconstituted samples is best stored at room temperature condition $\left(25^{\circ} \mathrm{C} / 60 \% \mathrm{Rh}\right)$. Product A showed a very good chemical, physicochemical and physical stability profile over time when compared with Product B and Product C. Thin layer chromatography show the presence of the degradation product after prolonged storage which underscores the importance of manufacturer instruction for storage and disposal of the product after usage. The increase in the absorbance of the reconstituted suspension after day 30. The impurities in commercial cefpodoxime proxetil samples were characterized based on MS/MS fragmentation pathways and chromatographic behaviours. In total, 15 impurities were detected have increase the kinetic energy of the individual particles of the molecules, thereby leading to an increase in their rate of collision which resulted in the samples being sticky. 
3. (1990) United States XXII Pharmacopeia, the United States Pharmacopeia Convention Inc, 12601 Twin brook Parkway, Rockville, MD 20852: 249250.

4. (1996) Indian Pharmacopeia, Ministry of health and family welfare, Govt. of India, New Delhi; controller of publication ( $2^{\text {nd }}$ edn.). A-740.

5. (1996) Indian Pharmacopeia, Ministry of health and family welfare, Govt. of India, New Delhi; controller of publication (4 ${ }^{\text {th }}$ edn.) A-54.

6. Camus F, Deslandes A, Harcouet L, Farinotti R (1994) High-performance liquid chromatographic method for the determination of cefpodoxime levels in plasma and sinus mucosa. J Chromatogr B Biomed Appl 17 656(2): 383-388.

7. RP Kotkar, AA Shirkhedkar, SJ Surana (2012) Int J Res Pharm Biomed Sci 3: 156-163.
8. Mills TJ, Roberson C (1987) Instrumental Data for Drug Analysis, (2 ${ }^{\text {nd }}$ edn.) Elsevier, Amsterdam 1: 367.

9. Todd WM (1994) International Journal of Antimicrobial Agents 4(1): 37-62.

10. Nakao H, Fujimoto K, Ishihara S, Sugawara S, Igarashi I, (Sankyo Company Limited), US Patent 4: 486-425.

11. Kim WJ, Ko KY, Jung MH, Kim M, Lee KI, et al. The Journal of Antibiotics 44(10): 1083-1087.

12. Kumar Y, Prasad M, Singh K, Misra S (Ranbaxy Laboratories Limited), US patent No. 7,045,618 B2.

13. Poras H (2014) Journal of Medicinal Chemistry 57(13): 5748-5763.

14. David FA, Roy OA Synthetic.

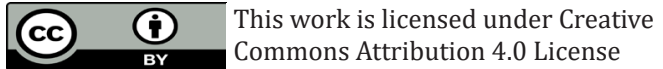

To Submit Your Article Click Here:

Submit Article

DOI: 10.32474/LOJMS.2018.01.000110

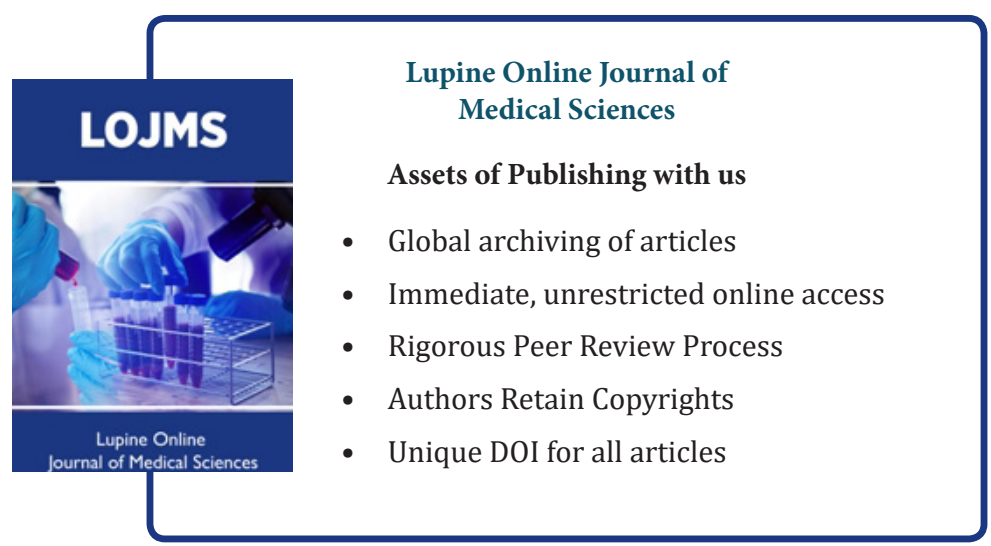

